\title{
Variability in ${ }^{137} \mathrm{Cs}$ inventories and potential climatic and lithological controls in the central Ebro valley, Spain.
}

\author{
A. Navas ${ }^{1}$, D.E. Walling ${ }^{2}$, T. Quine ${ }^{2}$, J. Machín ${ }^{1}$, J. Soto ${ }^{3}$, S. Domenech ${ }^{1}$, M. \\ López-Vicente ${ }^{1}$ \\ ${ }^{1}$ Department of Soil Science, Estación Experimental de Aula Dei. CSIC. Apartado \\ 202, 50080 Zaragoza (Spain). anavas@eead.csic.es \\ ${ }^{2}$ Department of Geography. University of Exeter. Amory Building. Rennes Drive. \\ Exeter EX4 4RJ. U.K. \\ ${ }^{3}$ Departamento de Ciencias Médicas y Quirúrgicas, Universidad de Cantabria, \\ Avenida Cardenal Herrera Oria s/n, 39011 Santander, Spain.
}

\begin{abstract}
The extent of soil erosion in some Spanish semiarid regions has caused great concern regarding the sustainability of soil resources. Accelerated soil erosion, particularly in some Mediterranean areas, is likely to be one of the main environmental problems associated with climate change. Fallout ${ }^{137} \mathrm{Cs}$ has been shown to provide a reliable basis for assessing soil erosion rates in different environments around the world. However, existing information concerning the spatial variation of ${ }^{137} \mathrm{Cs}$ inventories at reference sites has identified a need for further investigation of the factors affecting their spatial variability in semiarid environments, where stony and skeletal soils are predominant. Reference sites at three locations in the central Ebro valley were selected to investigate the ${ }^{137} \mathrm{Cs}$ content of
\end{abstract}


several grain size fractions. Each site included both natural vegetated conditions and cultivated land and the three sites were characterized by different values of mean annual rainfall. The results obtained demonstrate the influence of lithology, land use and climate on the spatial variability of ${ }^{137} \mathrm{Cs}$ inventories that increase from 1190 , to 1500 and $1710 \mathrm{~Bq}$ $\mathrm{m}^{-2}$ with increasing annual rainfall values from 300 to $500 \mathrm{~mm}$ at the study sites. The soils on marls at the Valareña site had the highest proportion of ${ }^{137} \mathrm{Cs}$ in the coarse fractions of cultivated soils (12 \%) in comparison with soils developed on limestones at Loma Negra (5\%), whereas no ${ }^{137}$ Cs content was found in the coarse fractions of soils on glacis-terrace materials at Peñaflor. The ${ }^{137}$ Cs reference inventories are higher in soils on marls and sands at cultivated locations at Valareña and Peñaflor, but have similar values in soils at cultivated and uncultivated locations on limestones at Loma Negra. Therefore, in absence of level undisturbed soils with natural vegetation cover, cultivated flat soils on hard rocks could provide reliable reference inventories.

Key words: ${ }^{137} \mathrm{Cs}$ reference inventories, physiographic factors, lithology, rainfall, land use, semiarid regions, central Ebro basin, Spain.

\section{Introduction}

Some semiarid regions in Spain, such as the central part of the Ebro valley, are suffering from severe erosion. The extent of this problem has caused much concern about the future of the fragile soil resources, and has emphasized the urgent need to implement soil conservation measures. A first step in this direction is to quantify actual erosion rates. The application of the ${ }^{137} \mathrm{Cs}$ technique to investigate erosion rates and patterns, provides a 
means of assessing the movement of soil particles within a globally-applicable worldwide framework. This radioisotope has been widely used in many different environments around the world ${ }^{1,2,3}$. From the first studies ${ }^{4,5,6}$ to more recent investigations ${ }^{7,8}$, the ${ }^{137}$ Cs technique has been applied successfully to trace soil movement and other environmental processes operating over the last 30 years.

Fallout ${ }^{137} \mathrm{Cs}$ has proved to be a reliable method for quantifying erosion processes in highly fragile environments, such as the semiarid steppe and temperate mountain areas in the central part of the Ebro basin ${ }^{9,10}$. Research carried out in the region ${ }^{11}$ (Las Bardenas area) showed that erosion rates on cultivated land were five times higher than on uncultivated land. In these existing studies, analyses of the spatial distribution of the ${ }^{137} \mathrm{Cs}$ inventories highlighted the need for further investigation of the factors affecting the spatial variability of ${ }^{137} \mathrm{Cs}$ reference inventories in these semiarid environments ${ }^{9}$, where stony and skeletal soils with high gravel content are predominant. This issue has also been subject of research in Australia ${ }^{12}$.

The work reported in this paper investigates the ${ }^{137}$ Cs levels found at three study sites located in the central Ebro valley. Each site includes both natural vegetated conditions and cultivated land under different mean annual rainfall. The aim is to analyze the influence of climatic, lithological and pedological factors on the local variability of ${ }^{137}$ Cs reference inventories. Among the lithological and pedological factors the nature and size of soil particles and aggregates may influence the final estimation of ${ }^{137} \mathrm{Cs}$ inventories. In order to assess this effect ${ }^{137}$ Cs measurements are performed in several grain size fractions These data may provide the basis for a better understanding of ${ }^{137}$ Cs behaviour in these semiarid environments that are characterized by irregular patterns of surface stoniness and vegetation cover, which affect the initial distribution of the radioisotope. 


\section{Study sites}

Three sites located along a climatic transect and representative of the most typical physiographic conditions found in the central Ebro valley were selected for this study (Figure 1). The main physiographic and land use characteristics of the three study sites are summarised in Table 1.

The landscape of the central Ebro basin is characterized by high Tertiary plateaux dissected by a fluvial network, draining towards the River Ebro. The Loma Negra site, named after one of these central plateaux, lies at an altitude of $600 \mathrm{~m}$ above sea level. This structural platform has carbonate materials at the hilltop on which Rendzic Leptosols have developed. These soils are poorly developed and their depth does not exceed 20-25 cm. Due to the flat terrain, much of the Loma Negra plateau is under cultivation for cereals, but in some areas relicts of a natural vegetation of pine trees (Pinus halepensis), Quercus coccifera and other shrubs species still remains.

The Valareña site is located at the foot of the Loma Negra plateau at an altitude of 400 $\mathrm{m}$ above sea level. It is underlayed by Miocene sandstones, marls and clays. The soils according to the FAO (Food and Agriculture Organization of the United Nations) classification are Leptosols. This level area is also intensively cultivated for agricultural crops, and very little natural vegetation remains.

The Peñaflor site is located near Zaragoza on the left bank of the Gallego river, at an altitude of $300 \mathrm{~mm}$ above sea level. The landscape here is smooth and undulating and the Tertiary gypsiferous hills are covered by Plioquaternary glacis materials, composed of sands, clays and abundant calcareous stones. The soils at this site are deeper and are 
classified as Calcisols. The site has a well developed forest of pine trees (Pinus halepensis). On the flatter areas, forest has been cleared for cultivation.

All the three study sites are almost level as they correspond to the tops of the plateau and hill landscapes of the central Ebro valley. The mean annual rainfall is $550 \mathrm{~mm}$ at Loma Negra, $450 \mathrm{~mm}$ at Valareña, and $300 \mathrm{~mm}$ at Peñaflor. The rainfall regime is similar in the three study sites. Rainfall is evenly distributed throughout the year around and is characterized by short and intense storm events.

\section{Sample collection and analysis}

At each of the three study sites, samples were collected from both uncultivated and cultivated land, i.e. two locations per site. The study sites were carefully selected to be reference sites. The uncultivated locations on communal rangeland were almost level and had undisturbed and stable soil covered by well preserved natural vegetation. The soil sampling at cultivated locations was established in nearby private farmlands that were also on flat terrain and had stable soils.

At each location, whole core samples were collected from a sampling grid comprising 9 points at Valareña and Peñaflor and 8 at Loma Negra due to the presence of rock outcrops. The sampling locations were of similar size with the sampling points spaced 1-2 m apart. Soil samples were collected using a $8.2 \mathrm{~cm}$ diameter corer. In order to examine the depth distribution of ${ }^{137} \mathrm{Cs}$ in the soil profile, the core collected from the centre of the grid network was sectioned into $5 \mathrm{~cm}$ depth increments. The depth of sampling was

selected in order to include the entire ${ }^{137} \mathrm{Cs}$ depth profile and was $30 \mathrm{~cm}$ for the uncultivated land and $40 \mathrm{~cm}$ for the cultivated land. 
A total of 52 samples were collected and these samples were air-dried and mill grinded to disaggregate the soil particles ensuring the break up of large soil aggregates. The individual samples were analysed to characterize their general properties, including: $\mathrm{pH}$, organic matter (OM), electrical conductivity (EC), carbonate content and stoniness, i.e. the relative proportion of coarse fragments $(>2 \mathrm{~mm})$ in the soil.

The $\mathrm{pH}$ (1:2.5 soil:water) and EC (1:5 soil:water) were measured using a pH-meter and a conductivity meter, respectively. Organic matter was determined by the Sanerlandt method ${ }^{13}$ using a titrimeter incorporating an ion selective electrode. Carbonates were measured using a pressure calcimeter ${ }^{14}$. The coarse fragments ( $>2$ $\mathrm{mm}$ ) were separated from the fine fractions $(<2 \mathrm{~mm})$ to what Cs-137 is strongly fixed. In order to separate the three grain-size fractions selected in this study: $<2 \mathrm{~mm}, 2-20 \mathrm{~mm}$ and $>20 \mathrm{~mm}$, they were passed through $2 \mathrm{~mm}$ and $20 \mathrm{~mm}$ sieves.

A total of 264 samples, of which 46 were bulk samples and 42 sectioned samples, were split into 3 size fractions and prepared for Cs-137 analyses. Cs-137 was measured by gamma spectrometry at the Department of Geography, University of Exeter, UK, using hyperpure coaxial Ge detectors coupled to a multichannel analyser. The samples were loaded into Marinelli beakers for gamma assay at $662 \mathrm{keV}$ and the counting times of $30000-60000$ s provided an analytical precision of ca. \pm 6 per cent at the $95 \%$ level of confidence. Cs-137 activity has been expressed per unit mass (Bq $\mathrm{kg}^{-1}$ ) or per unit area as the inventory $\left(\mathrm{Bq} \mathrm{m}^{-2}\right)$. 


\section{Results}

Information on selected soil properties for the uncultivated and cultivated locations at the study sites are presented in Table 2. The soils have very low salinity values and they are alkaline with high carbonate percentages that increase from Loma Negra, through Valareña to the Peñaflor study site. At all the study sites, the soils have slightly higher organic matter contents at the uncultivated locations. As shown in Figure 2 stoniness is a main soil component at Peñaflor and Valareña and in relation with lithology the lower contents are in soils at Loma Negra. The mean value of stoniness is around $30 \%$ at the cultivated and uncultivated locations of Loma Negra, although the lowest and highest values are both found at the uncultivated location the mean stoniness percentage exceeds $40 \%$ at Valareña and Peñaflor and higher contents are found within the cultivated location at Peñaflor, whereas the contrary is observed at Valareña (Table 3). Summary statistics of the mass distribution in the different granulometrical fractions found at the uncultivated and cultivated sites of the study areas is presented in Table 4.

Previous research conducted in adjacent areas ${ }^{9}$ demonstrated that no ${ }^{137}$ Cs fallout from the Chernobyl nuclear accident occurred at the study sites. The variability of the ${ }^{137} \mathrm{Cs}$ inventories at each study site has been analyzed. The particle size distribution and stoniness have been related to the distribution of ${ }^{137} \mathrm{Cs}$ inventories. As it can be seen in Figure 3, within the uncultivated location at the Valareña site, more than $94 \%$ of the total

${ }^{137} \mathrm{Cs}$ inventory is contained in the $<2 \mathrm{~mm}$ fraction. Therefore, little ${ }^{137} \mathrm{Cs}$ is present in the coarser fractions and no ${ }^{137}$ Cs was found in four of the nine samples.

At the Valareña cultivated location, the finer fraction accounts for $88 \%$ of the total

${ }^{137}$ Cs inventory. The radioisotope was found in all samples of the 2-20 mm fraction, which 
accounted for between 5 and $16 \%$ of the total ${ }^{137}$ Cs inventory. Low levels of ${ }^{137} \mathrm{Cs}$ were found in just one sample of the $>20 \mathrm{~mm}$ fraction.

The ${ }^{137}$ Cs inventories for the uncultivated locations show larger variations as indicated by the higher standard deviation. This conforms to previous reports of the higher variability found in rangelands ${ }^{15}$. In general, ${ }^{137} \mathrm{Cs}$ inventories are more homogeneous in cultivated areas, as indicated by the lower standard deviation (Table 5). This reflects the mixing effect of tillage that also has a strong effect on erosion in this area ${ }^{11}$. Furthermore, cultivation causes the breaking down of the stones within the marls to smaller sizes. The importance of the coarser fractions, 2-20 and $>20 \mathrm{~mm}$, within the cultivated location is therefore smaller than for the uncultivated location. The largest difference is found in the 2-20 mm fraction that is less abundant at the cultivated location (see Table 4), and conversely the finer fraction is more abundant, thus increasing the mass of particles able to adsorb ${ }^{137}$ Cs.

At Loma Negra, the proportion of the total ${ }^{137}$ Cs inventory contained in the $<2 \mathrm{~mm}$ fractions is similar for both uncultivated and cultivated locations (around 95\%). The average percentage of the total ${ }^{137} \mathrm{Cs}$ inventory in the $2-20 \mathrm{~mm}$ fractions at both the cultivated and uncultivated locations is around $4 \%$, which is lower than for the Valareña site. The content of ${ }^{137} \mathrm{Cs}$ of the $>20 \mathrm{~mm}$ fractions at both the cultivated and uncultivated locations is below $0.5 \%$.

In Peñaflor almost the whole ${ }^{137} \mathrm{Cs}$ inventory is contained in the $<2 \mathrm{~mm}$ fraction, and only three samples, two from the uncultivated location and one from the cultivated location, contain little ${ }^{137} \mathrm{Cs}$ in the coarse fractions.

The land use seems to affect most the ${ }^{137}$ Cs reference inventories in soils on marls at Valareña and to a lower extent at Peñaflor, where higher values are found at the cultivated 
locations. However, the effect of land use is almost negligible in soils on limestones at Loma Negra where ${ }^{137}$ Cs inventories are almost equal at cultivated and uncultivated locations (Table 5). In most cases cultivated soils are not used as reference sites, however in mountain regions that are intensively cultivated it is difficult to find flat terrain with undisturbed and stable soil. Therefore, in spite of soil movement derived from tillage, flat cultivated soils developed on hard rocks such as limestones could be suitable sites to establish reference inventories.

As it can be seen from Figure 4, for the three study sites a direct and highly significant relationship exists between the ${ }^{137} \mathrm{Cs}$ inventories of the fine fraction and the total ${ }^{137} \mathrm{Cs}$ inventories $(r=0.9)$. However, the relationship was not significant when the ${ }^{137} \mathrm{Cs}$ inventories of the coarse fractions were related to total ${ }^{137} \mathrm{Cs}$ inventories, because most ${ }^{137} \mathrm{Cs}$ in the coarse fragments was found in soils on marls from Valareña.

Therefore, the type of lithology exerts an important control on the presence of ${ }^{137} \mathrm{Cs}$ in the coarse fractions. Thus, soft rocks, such as the marls and clays of Valareña are able to retain some ${ }^{137} \mathrm{Cs}$ in the larger particles. This could also be due to coating of larger particles with finer particles. Research on Australian soils has also found high percentages of ${ }^{137} \mathrm{Cs}$ in the gravel fraction ${ }^{12}$. However, limestone which is the main component either as rock outcrop in Loma Negra, or as the sole stone component in Peñaflor does not contain ${ }^{137}$ Cs.

For all the study sites, the lower values of standard deviation for the cultivated locations indicate that the ${ }^{137} \mathrm{Cs}$ inventories associated with the different grain size fractions are more homogenous as a result of the mixing effect of tillage. Furthermore, since in areas of high stoniness the content of the fine fractions that are able to retain the 
radioisotope $^{16}$ is lower, it would be preferable to sample larger areas, in order to obtain reliable ${ }^{137}$ Cs inventories.

The different geographical location and altitude of the study areas affects the amount of total rainfall each site receives. There is a difference of around $100 \mathrm{~mm}$ per year between the three study sites. The highest annual rainfall is found at Loma Negra (500-550 mm), with lower values at Valareña (450 mm) and Peñaflor (300 mm). There is a clear relationship between the average ${ }^{137} \mathrm{Cs}$ inventories and the mean annual rainfall for the three study sites, as values increase from 1190, to 1500 and $1710 \mathrm{~Bq} \mathrm{~m}{ }^{-2}$ in Peñaflor, Valareña and Loma Negra, respectively (Figure 5). These differences therefore reflect the initial variation of ${ }^{137} \mathrm{Cs}$ fallout, which would increase in line with the increase in annual rainfall from Peñaflor to Loma Negra. The impact of the variation of annual rainfall on the ${ }^{137} \mathrm{Cs}$ inventories is more marked for uncultivated land than for cultivated land, since tillage homogenizes the radioisotope distribution within the soil.

\section{Conclusions}

To establish reliable reference inventories and to take account of the spatial variability of inventories found at reference sites in these semiarid environments, there is a need to include the 2-20 mm fraction in the ${ }^{137} \mathrm{Cs}$ analysis for soft rocks, such as marls, because the traditional procedure of sieving to $<2 \mathrm{~mm}$ could underestimate the inventory especially for cultivated soils. There appears to be no need to include the $>20 \mathrm{~mm}$ fraction for soils developed on hard rocks or containing limestone. Furthermore, because in semiarid mountain environments level and undisturbed sites are scarce the sampling of flat cultivated soils on hard rocks could be an alternative to establish suitable reference 
inventories. These data may provide a basis for a better understanding of ${ }^{137} \mathrm{Cs}$ behaviour in these semiarid environments, with sparse vegetation cover and soils with a high stone content causing an increase in the variability of the initial spatial distribution of the radioisotope.

\section{Acknowledgements}

The work reported received financial support from CICYT projects RADIERO (REN2002-02702/GLO) and REM (CGL2005-02009/BTE). This support is gratefully acknowledged.

\section{References}

${ }^{1}$ R. J. LOUGHRAN, B. L. CAMPBELL, G.L. ELLIOT, Soil erosion in Agricultural Land, Ed. Wiley and Sons, Chichester, (1990) p. 119.

²J.C. RITCHIE, J. R.McHENRY, J. Environ. Qual., 9 (1990) 215.

${ }^{3}$ D. E.WALLING, T. A. QUINE, J. Soil Sci. 42 (1991)147.

4J. C. RITCHIE, J. R. McHENRY, A. C. GILL, Ecology, 55 (1974) 887.

${ }^{5}$ D. E. WALLING, S. B.BRADLEY, C. J.WILKINSON, IAHS Publi. 159 (1986) 423.

${ }^{6}$ L. W. MARTZ, E. DE JONG, Catena, 14 (1987) 439.

${ }^{7}$ Y. N. BANIS, J. C. BATHURST, D. E. WALLING, Hydrol. Proc.18 (2004) 795.

${ }^{8}$ C. PAPASTEFANOU, J. Radioanal. Nucl. Chem. 267 (2006) 315.

${ }^{9}$ A. NAVAS, D. E. WALLING, IAHS Publ. 209 (1992) 129.

${ }^{10}$ A. NAVAS, J. MACHÍN, J. SOTO, Agr. Ecosyst.. Environ., 105 (2005) 493. 
${ }^{11}$ T. QUINE, A. NAVAS, D. E. WALLING, J. MACHÍN, Land Degrad. Rehabil., 5 (1994) 41.

12 D. J. MACFARLANE, R. J. LOUGHRAN, B. L.CAMPBELL, Aust. J. Soil Res. 30 (1992) 533.

${ }^{13}$ F. GUITIAN, T. CARBALLAS, Técnicas de análisis de suelos, Ed. Pico Sacro, Santiago de Compostela, Spain, (1976) p. 288.

${ }^{14}$ CSIC, Anal. Edafol. Agrobiol., 35 (1976) 813.

${ }^{15}$ A. NAVAS, J. M. GARCIA-RUIZ, J. MACHÍN, T. LASANTA, D. E. WALLING, T. QUINE, B. VALERO, IAHS Publ., 245 (1997) 13.

${ }^{16}$ J. SOTO, A. NAVAS, 2004. J. Arid Environ. 59 (2004) 719. 


\section{Figure captions}

1.- The location of the study sites in the Ebro basin.

2.- The percentage of the total mass in the different grain size fractions at the uncultivated and cultivated locations at the study sites.

3.- The percentage of the total ${ }^{137} \mathrm{Cs}$ inventories accounted for by the different grain size fractions at the uncultivated and cultivated locations at Valareña and Loma Negra.

4.- Relationships between the total ${ }^{137} \mathrm{Cs}$ inventories and the ${ }^{137} \mathrm{Cs}$ inventories of the fine fraction and the coarse fractions for the study sites.

5.- Mean and standard deviations of ${ }^{137}$ Cs inventories for the study sites. 


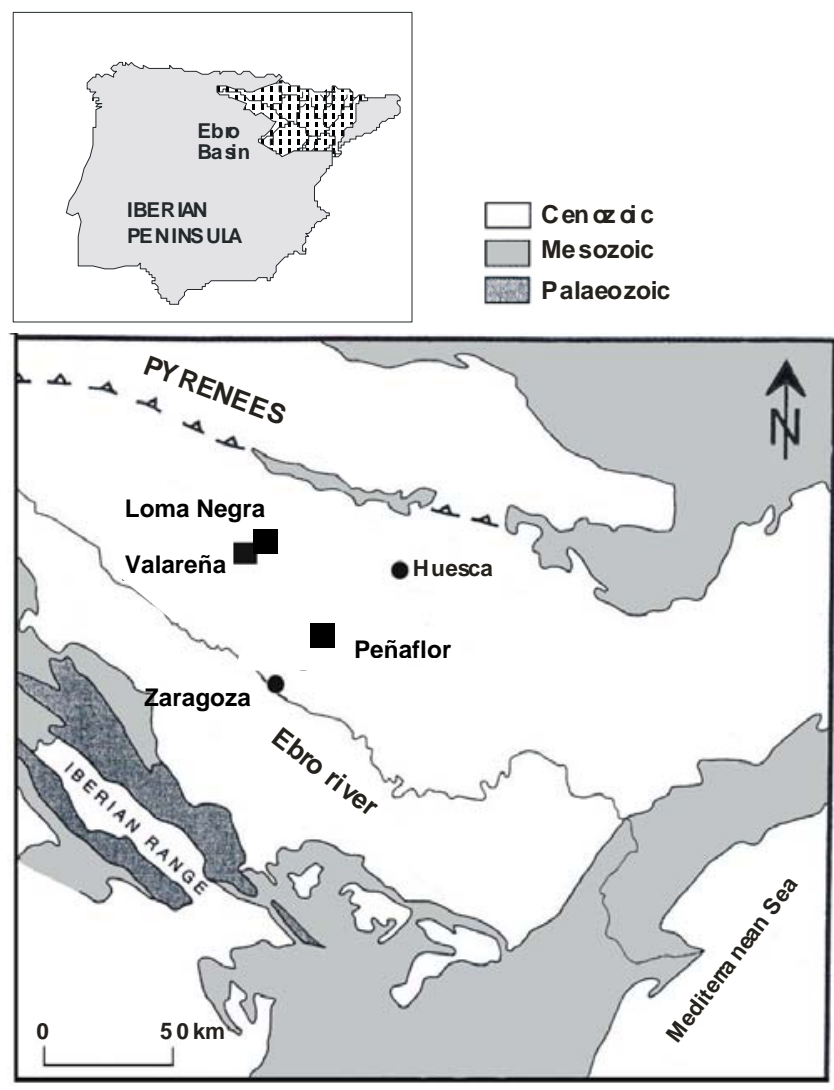

Figure 1. 

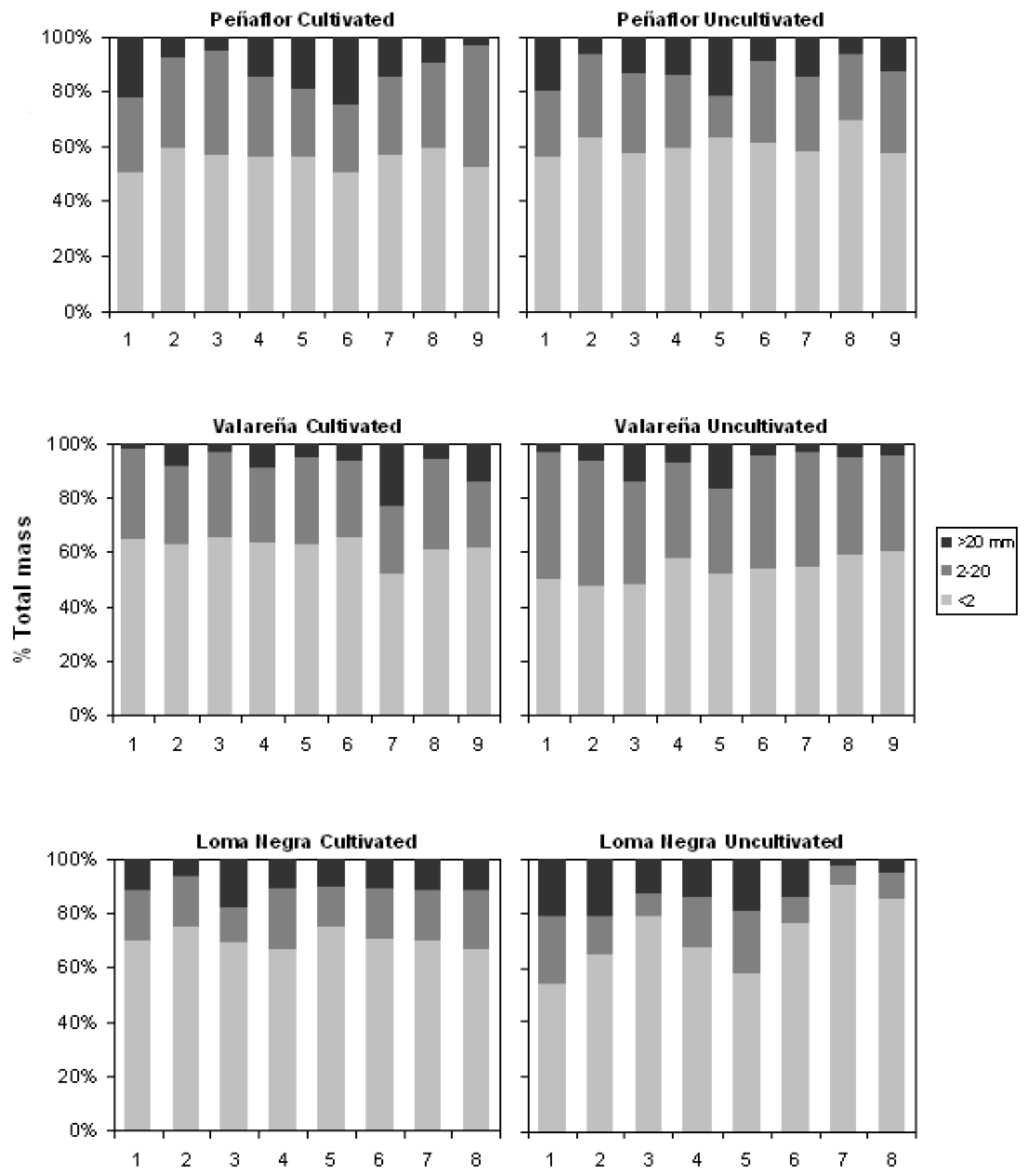

Soil samples

Figure 2 


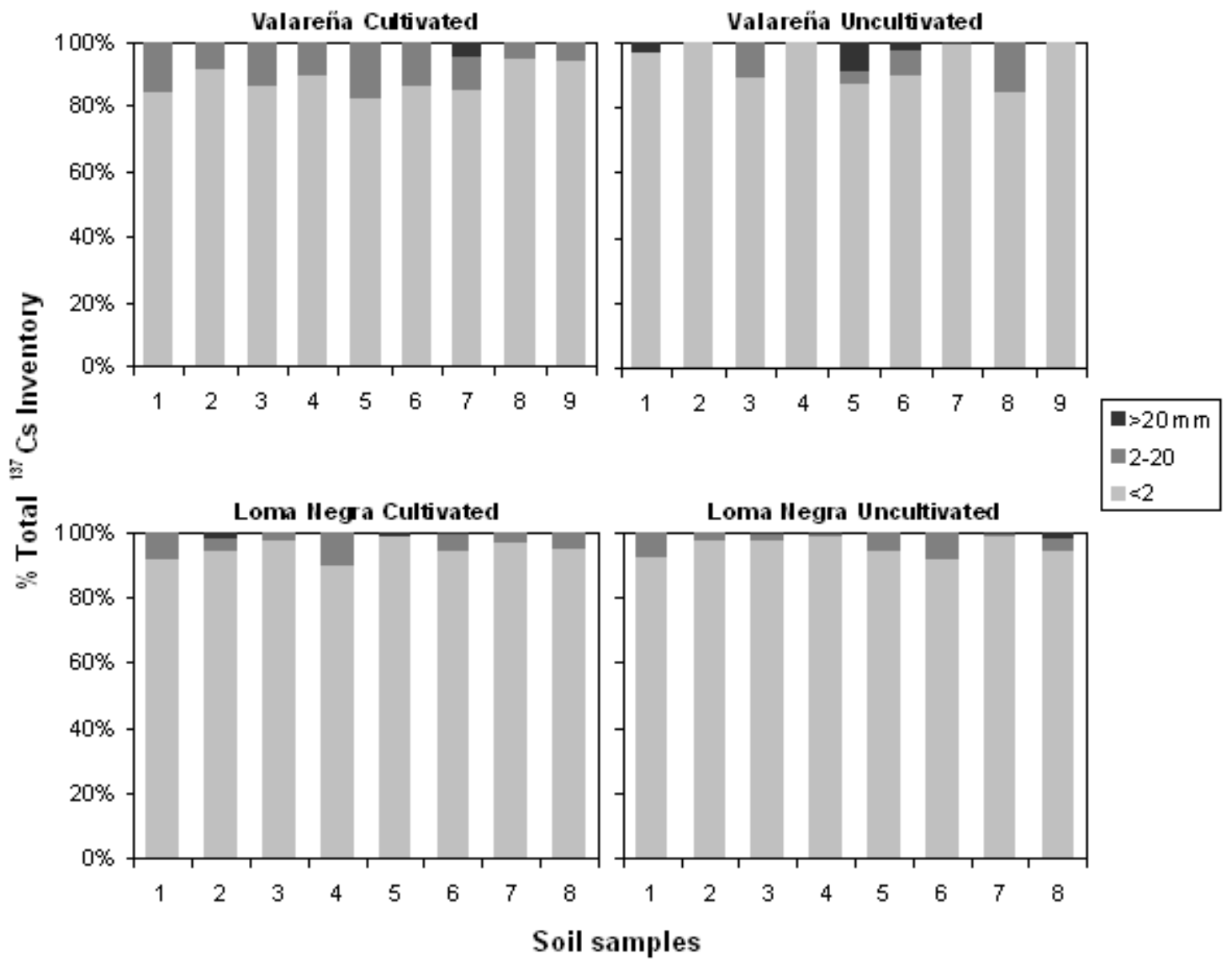

Figure 3. 

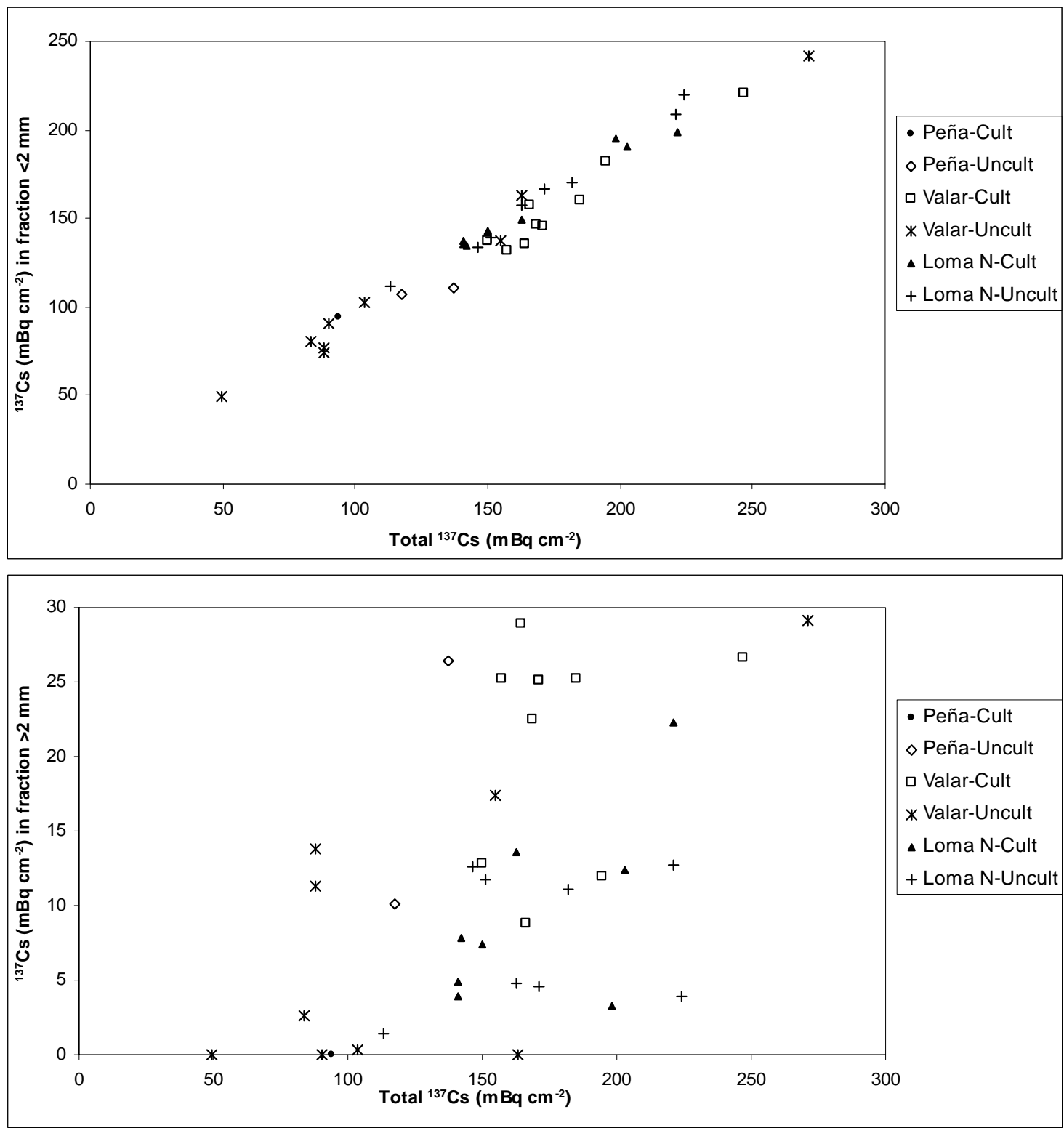

Figure 4 


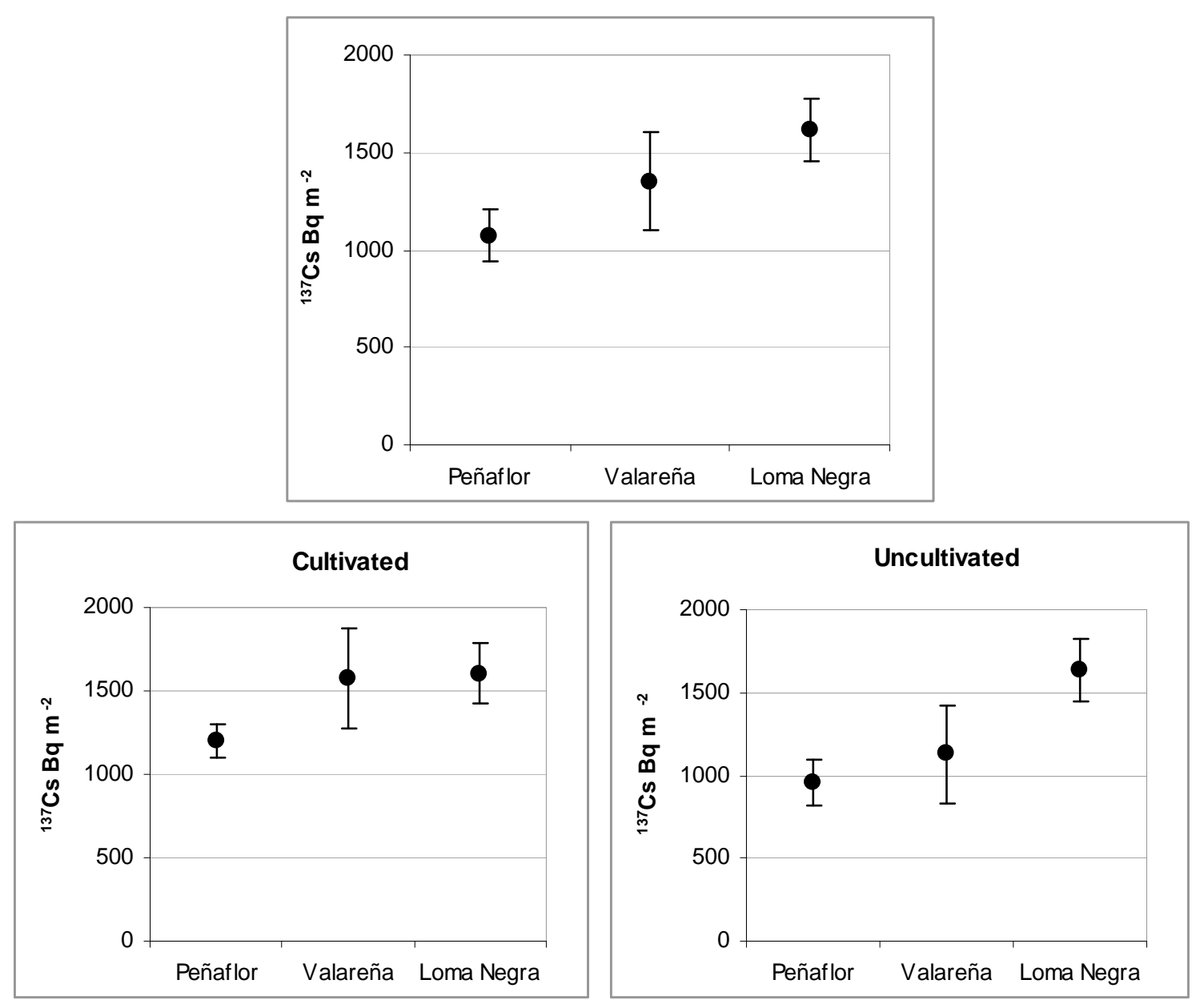

Figure 5 
Table 1. Main physiographic and land characteristics of the study sites.

\begin{tabular}{|c|c|c|c|c|c|c|c|}
\hline Site & Climate & Landscape & $\begin{array}{c}\text { Altitude } \\
\text { (m) }\end{array}$ & Vegetation & $\begin{array}{c}\text { Rainfall } \\
\text { (mm) }\end{array}$ & Soil types & $\begin{array}{c}\text { Parent } \\
\text { material }\end{array}$ \\
\hline $\begin{array}{l}\text { Loma } \\
\text { Negra }\end{array}$ & $\begin{array}{l}\text { semiarid- } \\
\text { temperate }\end{array}$ & plateaux & 600 & $\begin{array}{l}\text { matorral, } \\
\text { pines, cereals }\end{array}$ & 500 & $\begin{array}{l}\text { Rendzic } \\
\text { Leptosols }\end{array}$ & Limestones \\
\hline Valareña & semiarid & plateaux & 400 & $\begin{array}{l}\text { shrubs, cereals, } \\
\text { fallow }\end{array}$ & 450 & Leptosols & marls, clays \\
\hline Peñaflor & $\begin{array}{l}\text { semiarid- } \\
\text { arid }\end{array}$ & hills & 300 & $\begin{array}{l}\text { pines, shrubs, } \\
\text { cereals } \\
\text { fallow }\end{array}$ & 300 & Calcisols & $\begin{array}{l}\text { glacis: sands, } \\
\text { limestones }\end{array}$ \\
\hline
\end{tabular}


Table 2. Soil properties at the study sites.

\begin{tabular}{|c|c|c|c|c|c|c|}
\hline Studied area & Land use & pH & $\begin{array}{c}\text { OM } \\
\%\end{array}$ & $\begin{array}{c}\mathrm{CO}_{3}= \\
\%\end{array}$ & $\begin{array}{c}\text { Stoniness } \\
\%\end{array}$ & $\begin{array}{c}\text { Electrical } \\
\text { conductivity } \\
\mathrm{dSm}^{-1}\end{array}$ \\
\hline Loma Negra & $\begin{array}{l}\text { cultivated } \\
\text { uncultivated }\end{array}$ & $\begin{array}{l}8.5 \\
8.5\end{array}$ & $\begin{array}{l}3.5 \\
4.1\end{array}$ & $\begin{array}{l}28.9 \\
23.9\end{array}$ & $\begin{array}{l}29.7 \\
28.3\end{array}$ & $\begin{array}{l}0.191 \\
0.186\end{array}$ \\
\hline Valareña & $\begin{array}{l}\text { cultivated } \\
\text { uncultivated }\end{array}$ & $\begin{array}{l}8.3 \\
8.2\end{array}$ & $\begin{array}{l}4.8 \\
6.1\end{array}$ & $\begin{array}{l}35.1 \\
37.7\end{array}$ & $\begin{array}{l}38.0 \\
46.4\end{array}$ & $\begin{array}{l}0.306 \\
1.390\end{array}$ \\
\hline Peñaflor & $\begin{array}{l}\text { cultivated } \\
\text { uncultivated }\end{array}$ & $\begin{array}{l}8.2 \\
8.5\end{array}$ & $\begin{array}{l}4.1 \\
4.9\end{array}$ & $\begin{array}{l}55.2 \\
42.5\end{array}$ & $\begin{array}{l}44.7 \\
39.6\end{array}$ & $\begin{array}{l}0.347 \\
0.193\end{array}$ \\
\hline
\end{tabular}


Table 3. Basic statistics of the stoniness percentages for both the cultivated and uncultivated locations at the study sites a) and separately for the cultivated and uncultivated locations b).

a) mean sd. $\min \max$

Peñaflor $\begin{array}{llll}42.1 & 4.6 & 30.4 & 49.6\end{array}$

Valareña $\begin{array}{llll}42.2 & 6.0 & 34.9 & 52.7\end{array}$

Loma Negra $\begin{array}{llll}29.0 & 9.2 & 9.4 & 46.5\end{array}$

b)

\begin{tabular}{crcc}
\multicolumn{2}{c}{ Cultivated } & \multicolumn{3}{c}{ Uncultivated } \\
mean & sd. min $\max$ mean sd. min $\max$ \\
\hline
\end{tabular}

Peñaflor

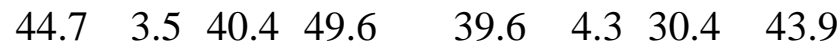

Valareña $\begin{array}{llllllll}38.0 & 4.2 & 34.9 & 48.6 & 46.3 & 4.6 & 40.0 & 52.7\end{array}$

Loma Negra $\begin{array}{llllllll}29.7 & 3.4 & 24.6 & 33.4 & 28.3 & 13.0 & 9.4 & 46.5\end{array}$ 
Table 4. Basic statistics of the total mass distribution in the three grain size fractions at the studied sites.

\begin{tabular}{|c|c|c|c|c|c|c|c|c|}
\hline \multirow[b]{2}{*}{$<2 \mathrm{~mm}$} & \multicolumn{4}{|c|}{ Cultivated } & \multicolumn{4}{|c|}{ Uncultivated } \\
\hline & mean & sd. & $\min$ & $\max$ & mean & sd. & $\min$ & $\max$ \\
\hline Peñaflor & 55.3 & 3.5 & 50.4 & 59.6 & 60.5 & 4.3 & 56.1 & 69.6 \\
\hline Valareña & 62.0 & 4.2 & 51.4 & 65.1 & 53.7 & 4.6 & 47.3 & 60.0 \\
\hline Loma Negra & 70.3 & 3.4 & 66.6 & 75.4 & 71.7 & 13.0 & 53.5 & 90.6 \\
\hline
\end{tabular}

\begin{tabular}{|c|c|c|c|c|c|c|c|c|}
\hline 2- $20 \mathrm{~mm}$ & mean & sd. & $\min$ & $\max$ & mean & sd. & $\min$ & $\max$ \\
\hline Peñaflor & 31.1 & 6.4 & 24.8 & 44.6 & 26.3 & 4.7 & 15.8 & 30.1 \\
\hline Valareña & 29.4 & 3.3 & 23.9 & 33.3 & 39.1 & 5.3 & 30.9 & 46.5 \\
\hline Loma Negra & 18.2 & 3.2 & 13.2 & 22.4 & 14.4 & 7.1 & 6.7 & 25.4 \\
\hline
\end{tabular}

\begin{tabular}{|c|c|c|c|c|c|c|c|c|}
\hline$>20 \mathrm{~mm}$ & mean & sd. & $\min$ & $\max$ & mean & sd. & $\min$ & $\max$ \\
\hline Peñaflor & 13.6 & 7.5 & 3.3 & 24.8 & 13.2 & 5.3 & 6.7 & 21.6 \\
\hline Valareña & 8.6 & 6.3 & 2.4 & 22.8 & 7.2 & 4.9 & 3.2 & 17.1 \\
\hline Loma Negra & 11.5 & 3.1 & 6.9 & 17.9 & 13.9 & 6.9 & 2.7 & 21.1 \\
\hline
\end{tabular}


Table 5.- Basic statistics of ${ }^{137} \mathrm{Cs}$ inventories $\left(\mathrm{Bq} \mathrm{m}^{-2}\right)$ in the three grain size fractions at the cultivated and uncultivated locations at the study sites.

\section{Cultivated}

$<2 \mathrm{~mm}$

Peñaflor

Valareña

Loma Negra

\begin{tabular}{rrrrrrrrr} 
mean & sd. & min & $\max$ & & mean & sd. & $\min$ & $\max$ \\
\cline { 1 - 1 } 1194 & 188 & 939 & 1524 & & 953 & 259 & 621 & 1437 \\
1574 & 266 & 1321 & 2203 & & 1130 & 560 & 493 & 2421 \\
1604 & 271 & 1343 & 1991 & & 1636 & 344 & 1115 & 2201
\end{tabular}

2- $20 \mathrm{~mm}$ mean sd.

Peñaflor

Valareña

Loma Negra

\begin{tabular}{rrrrrrrr} 
mean & sd. & min & max & mean & sd. & $\min$ & $\max$ \\
\hline 0 & 0 & 0 & 0 & 119 & 84 & 60 & 179 \\
200 & 73 & 88 & 289 & 62 & 87 & 0 & 213 \\
84 & 68 & 0 & 222 & 69 & 45 & 6 & 123
\end{tabular}

$>20 \mathrm{~mm}$

mean sd.

$\min \max$

mean sd.

$\min \max$

Peñaflor

Valareña

Loma Negra

$\begin{array}{rrrr}0 & 0 & 0 & 0 \\ 8 & 25 & 0 & 74 \\ 16 & 19 & 0 & 41\end{array}$

$63 \quad 3$

41

$24 \quad 35$

0

$10 \quad 16$

$0 \quad 48$

Total fractions

\begin{tabular}{rrrrrrrr} 
mean & sd. & min & max & mean & sd. & $\min$ & $\max$ \\
\hline & & & & & & & \\
1194 & 188 & 939 & 1524 & 993 & 294 & 621 & 1437 \\
1783 & 274 & 1501 & 2469 & 1213 & 627 & 493 & 2712 \\
1698 & 305 & 1407 & 2213 & 1715 & 351 & 1130 & 2240
\end{tabular}

Peñaflor

Valareña

Loma Negra

2240 